\title{
Lacrimal sac mucoepidermoid carcinoma
}

\author{
J BLAKE,' JOAN MULLANEY,' AND J GILLAN ${ }^{2}$
}

From the 'Royal Victoria Eye and Ear Hospital, and ${ }^{2}$ Rotunda Hospital, Dublin, Ireland

SUMMARY A single case of mucoepidermoid carcinoma of the lacrimal sac was considered worth reporting as there are only four other cases described in the literature. The importance of the correct histological diagnosis and the management are discussed. This appears to be the first study of the ultrastructure of lacrimal sac mucoepidermoid tumour.

Mucoepidermoid carcinoma is a tumour composed of neoplastic mucin-producing cells and epidermoid cells. Although it most frequently affects the salivary glands it has also been reported in the ophthalmological literature in the conjunctiva ${ }^{1-3}$, lacrimal gland ${ }^{4}$, and lacrimal $\operatorname{sac}^{2}$.

\section{Case history}

A 78-year-old woman was seen in December 1979 for examination of a swelling in the region of the left lacrimal sac which had been present for some months. Her corrected visual acuity was right eye $2 / 60$, left eye $6 / 6$. Uncomplicated intracapsular

Correspondence to Joan Mullaney, MD, National Ophthalmic Pathology Laboratory and Registry of Ireland, Royal Victoria Eye and Ear Hospital, Adelaide Road, Dublin 2, Ireland. cataract extraction had been performed on the right eye in 1977 , but the central vision had remained poor owing to maculopathy attributed to injury some years before.

A firm, solid, painless mass was palpable in the left lacrimal fossa. There was no proptosis and no discharge on pressure on the sac. X-rays of the orbits and paranasal sinuses revealed one large ethmoid cell on the left side with smooth margins, but tomography of maxillary ${ }^{5}$ and orbital areas revealed no evidence of bone destruction. At surgery the mass was found to be adherent to skin and firmly fixed to underlying periosteum. When removed it measured $14 \times 8 \times 6$ $\mathrm{mm}$.

Pathological examination showed a mass of fibrous tissue in which lay scattered numerous islands of squamous cells (Fig. 1) in different configurations.

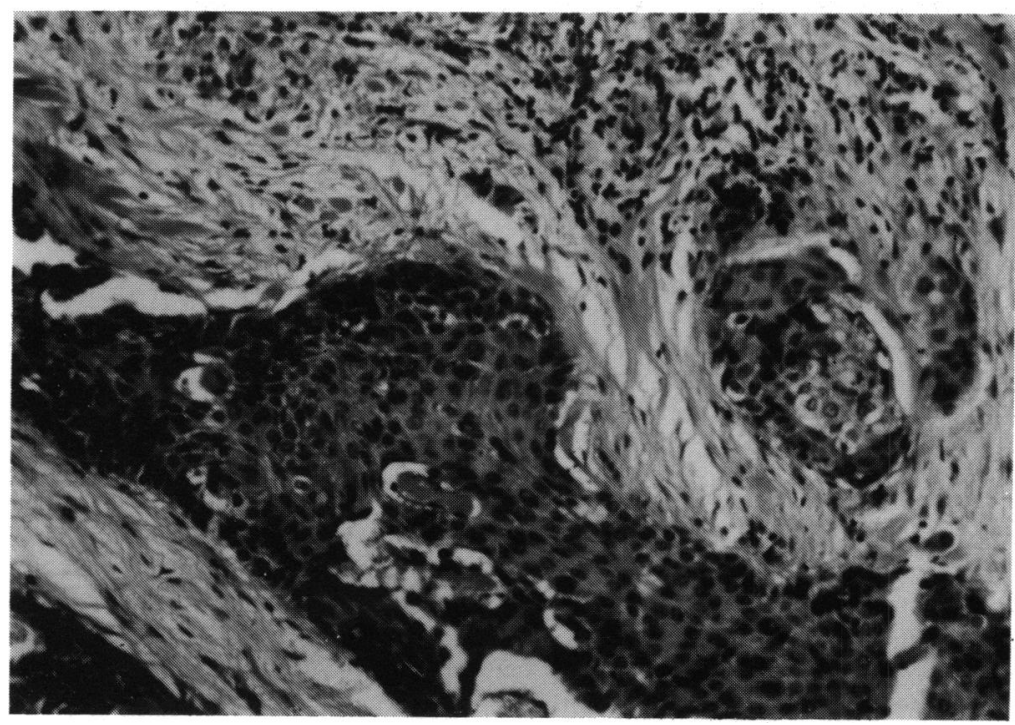

Fig. 1 Squamous cell clumps. (H\& E, ×32). 
Fig. 2 Squamous cells and microcystic area. $(\mathrm{H} \& \mathrm{E}, \times 32)$.

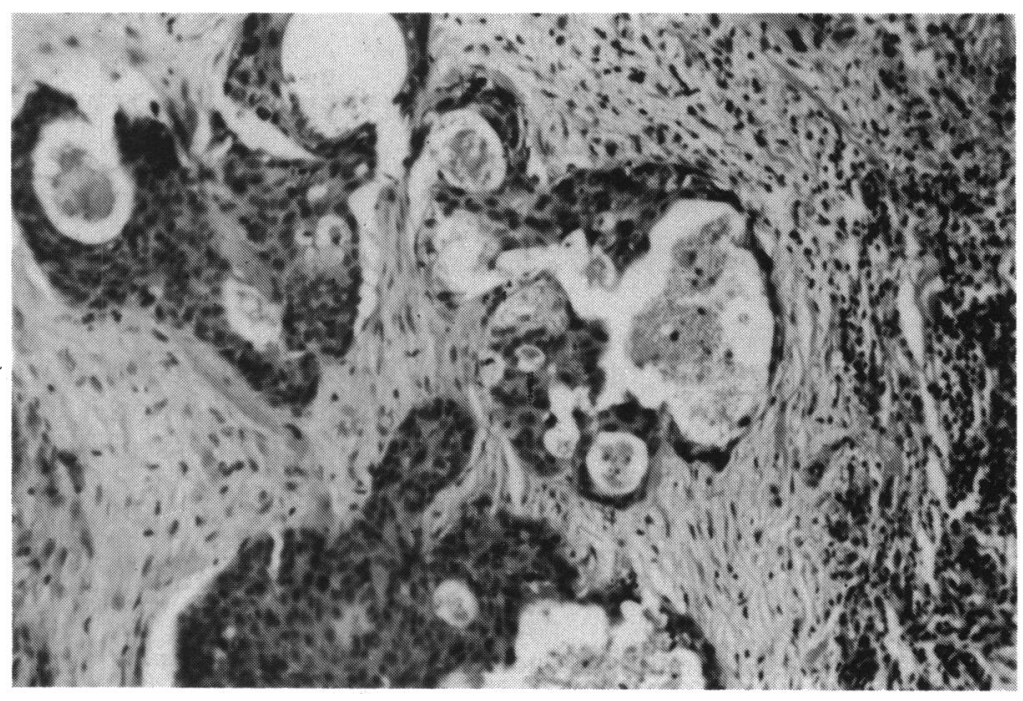

There were foci of microcystoid (Fig. 2) areas which stained positively for mucin, and many scattered clear cells could be seen. Bundles of voluntary muscle were scattered throughout, with evidence of muscle invasion as well as some degree of secondary myositis. In focal epithelial aggregations the cells could be described as being transitional in type. There was a moderate amount of mitotic activity. The histological diagnosis was that of a typical mucoepidermoid carcinoma.

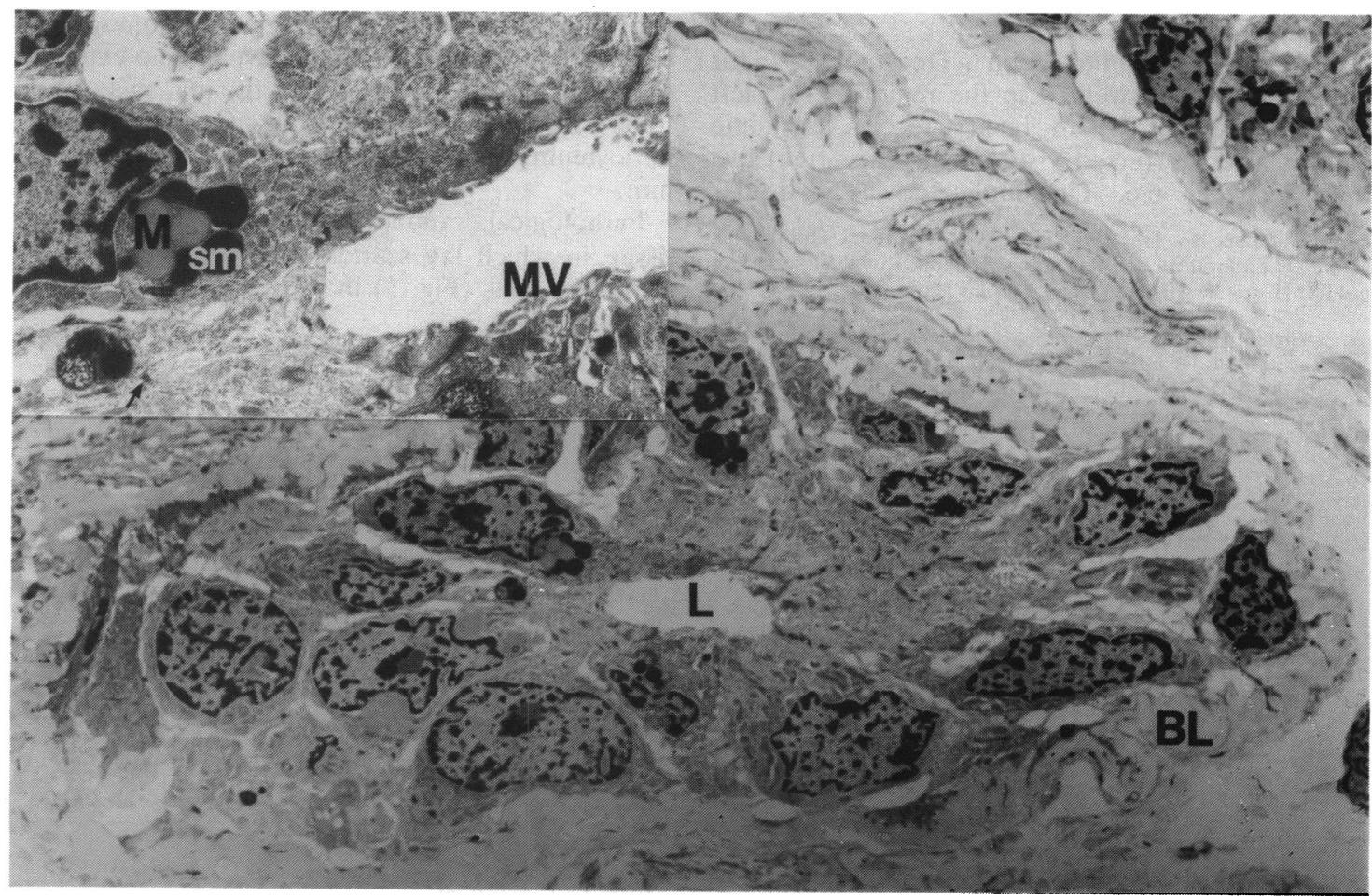

Fig. 3 Electron micrograph. Columnar and polygonal shaped cells, bound by a basal lamina (BL) and forming a lumen (L). The luminal surfaces bear microvilli (MV) and desmosomes are identifiable. Mucin (M) and seromucin (SM) vacuoles are present in some of the cells (insert). $(\times 2600$, inset $\times 9400)$. 


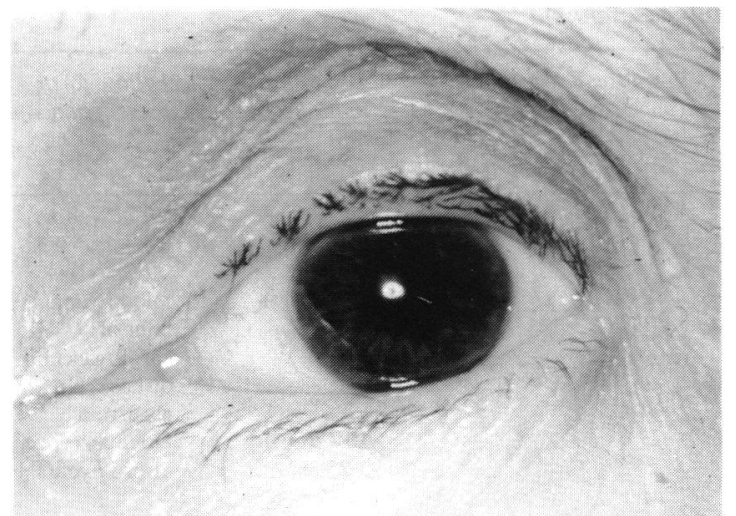

Fig. 4 Appearance after first operation-slight epiphora.

Tumour tissue in $1 \mathrm{~mm}$ cubes was removed from the paraffin embedded specimen and processed for electron microscopy. The tumour cells, which were polygonal, elongated, and columnar, were surrounded by a basal lamina, to which they appeared attached. Both mucous cells and intermediate cells were found in close association with occasional lumen formation (Fig. 3). The mucus-secreting cells contained membrane bound mucin, filled vacuoles, and occasional seromucinous secretory vacuoles. Some cells also contained endoplasmic reticulum. Mitochondria, fine filaments, and glycogen granules were either absent or inconspicuous. Desmosomes and tonofilaments were easily identified. The luminal surface of both the mucus-secreting and the intermediate cells were characterised by microvilli.

Examination by a specialist physician revealed no sign of metastatic spread and an ear, nose, and throat examination revealed no abnormality (Eric Fenelon, FRCSI). Thereafter she remained symptom-free

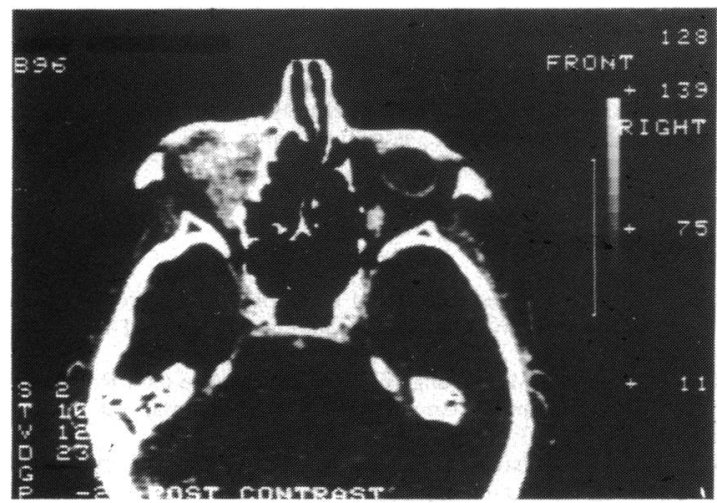

Fig. 5 Infiltrating, enhancing, soft tissue mass along medial margin of orbit.
(Fig. 4) for $3 \frac{1}{2}$ years apart from a brief period of slight epiphora.

In December 1983 the patient attended again with a firm mass which displaced the eye upwards and forwards and was disposed in crescentric manner from the inner half of the left upper eyelid, around the inner canthus and into the medial two-thirds of the lower eyelid.

Ultrasonography showed two deposits on the medial side of the orbit, the more anterior of which was situated $6 \mathrm{~mm}$ behind the anterior corneal plane. Computerised tomography scan (Fig. 5) (after intravenous contrast) disclosed an infiltrating, enhancing, soft tissue mass along the medial margin of the left orbit, extending laterally to the globe and anteriorly also towards the medial canthus, the bulk of the tumour being located in the medial interior part of the orbit. There was no evidence of bone destruction. A biopsy showed a similar appearance to the original specimen, the squamous cells being morphologically very prominent. Mucin was also identified.

At subsequent operation (Fig. 6), in March 1984, as much of the tumour as could be removed without damage to the eye was excised. Microscopic examination of this most recent specimen showed mucoepidermoid tumour with considerable dedifferentiation and with hyperchromatism and mitotic activity. Normal lacrimal sac mucosa was identified, with tumour in the deeper layers, and there was extensive infiltration of muscle.

In December 1984, five years after the patient first presented, she retained a visual acuity of $6 / 9$ in the left eye, though that had now become immobile and showed lagophthalmos and early signs of exposure keratitis. She declined further surgery on grounds of age and general frailty.

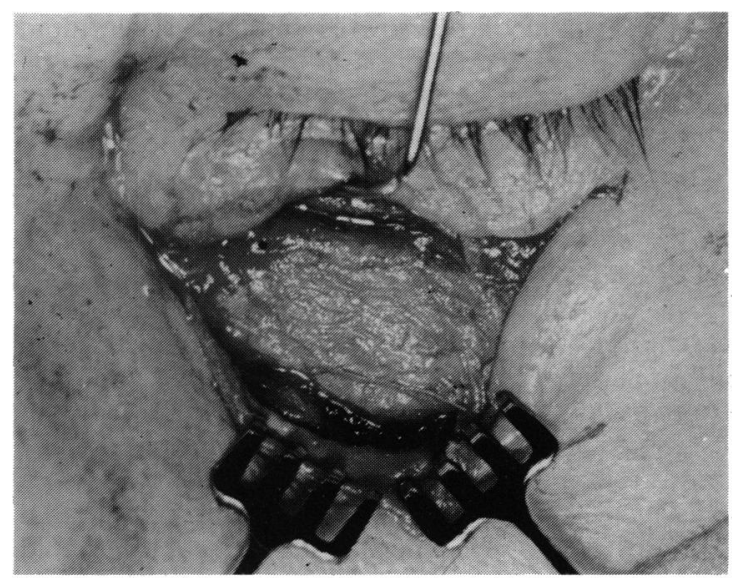

Fig. 6 Recurrence of tumour-early stage in surgical exposure. 
Table 1 Summary of reported cases of lacrimal sac mucoepidermoid carcinoma

\begin{tabular}{|c|c|c|c|c|c|c|c|c|c|c|c|c|c|}
\hline \multirow[t]{2}{*}{ Authors } & \multirow{2}{*}{$\begin{array}{l}\text { Age, } \\
\text { Sex, } \\
\text { Race }\end{array}$} & \multirow[t]{2}{*}{ Mass } & \multirow[t]{2}{*}{ Pain } & \multicolumn{3}{|c|}{ Discharge } & \multirow{2}{*}{$\begin{array}{l}\text { Duration } \\
\text { of } \\
\text { symptoms } \\
\text { (years) }\end{array}$} & \multirow{2}{*}{$\begin{array}{r}\text { Proptosis } \mathrm{E} \\
\boldsymbol{n} \\
\boldsymbol{r}\end{array}$} & \multirow{2}{*}{$\begin{array}{l}\text { Extra- } \\
\text { ocular } \\
\text { muscle } \\
\text { restriction }\end{array}$} & \multirow{2}{*}{$\begin{array}{l}\text { Bone } \\
\text { destruc- } \\
\text { tion on } \\
\text { X-ray }\end{array}$} & \multirow{2}{*}{$\begin{array}{l}\text { Size of } \\
\text { mass in } \\
m m\end{array}$} & \multirow{2}{*}{$\begin{array}{l}\text { Exent- } \\
\text { eration }\end{array}$} & \multirow{2}{*}{$\begin{array}{l}\text { Follow-up or } \\
\text { present status }\end{array}$} \\
\hline & & & & Watery & Purulent & Bloody & & & & & & & \\
\hline $\begin{array}{l}\text { Bambirra } \\
\text { et al. }{ }^{5}\end{array}$ & $\begin{array}{l}58 \\
\text { M } \\
\text { Brazilian }\end{array}$ & + & + & + & - & - & 2 & + & + & - & $\begin{array}{l}10 \times 8 \\
\text { (max. } \\
\text { diam.) }\end{array}$ & + & $\begin{array}{l}\text { Well } 2 \text { years } \\
\text { later }\end{array}$ \\
\hline Nietal. ${ }^{2}$ & $\begin{array}{l}60 \\
\text { M } \\
\text { Chinese }\end{array}$ & + & - & - & - & - & 3 & - & - & + & $\begin{array}{l}20 \times 20 \\
\times 15\end{array}$ & + & $\begin{array}{l}\text { Died } 1 \text { year } \\
\text { later of } \\
\text { cardiovascular } \\
\text { disease. No } \\
\text { recurrence }\end{array}$ \\
\hline Nietal. ${ }^{2}$ & $\begin{array}{l}40 \\
\text { F } \\
\text { Chinese }\end{array}$ & + & - & + & + & + & 2 & + & + & + & $\begin{array}{l}30 \times 25 \\
\times 25\end{array}$ & + & $\begin{array}{l}\text { No recurrence } \\
\text { after } 17 \text { years }\end{array}$ \\
\hline Niet al. ${ }^{2}$ & $\begin{array}{l}19 \\
\text { F } \\
\text { Chinese }\end{array}$ & + & - & - & + & - & 1 & - & - & + & $\begin{array}{l}30 \times 30 \\
\times 15\end{array}$ & + & $\begin{array}{l}\text { No recurrence } \\
\text { after } 5 \text { years }\end{array}$ \\
\hline $\begin{array}{l}\text { Blake } \\
\text { etal., this } \\
\text { paper }\end{array}$ & $\begin{array}{l}78 \\
\text { F } \\
\text { Irish }\end{array}$ & + & - & - & - & - & $1 / 4$ & + & + & - & $\begin{array}{l}14 \times 8 \\
\times 6\end{array}$ & - & $\begin{array}{l}\text { Well } 5 \text { years } \\
\text { later, but eye } \\
\text { fixed, exposure } \\
\text { keratitis }\end{array}$ \\
\hline
\end{tabular}

\section{Discussion}

The occurence of this tumour in other sites is well defined in both the pathological and general surgical literature. Seven cases have been reported in the conjunctiva ${ }^{136}$. Harry and Ashton ${ }^{7}$ reviewed lacrimal sac tumours in the files in the Department of Pathology at the Institute of Ophthalmology in London over a 20-year period (1948-1967). Thirteen cases were found, eight being epithelial in origin, and they concluded that all of these were of transitional cell type. They proposed a classification of: type 1 (transitional cell papilloma); type 2 (intermediate transitional cell tumour); and type 3 (transitional cell carcinoma). Squamous metaplasia was a feature of many of the growths, but mucoepidermoid tumours per se were not described. So far as can be ascertained, there are only four reports of mucoepidermoid tumours arising in the lacrimal sac, the first case being described in Brazil in 1981 by

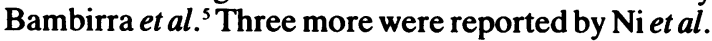
(1983) from Shanghai. ${ }^{2}$ Table 1 summarises these reports and includes the present case.

$\mathrm{Ni}$ et al. ${ }^{2}$ postulate that mucoepidermoid carcinoma in the lacrimal sac area may arise from either lacrimal sac mural serous gland epithelium or from the columnar epithelium of the conjunctiva with its goblet cells. These tumours may infiltrate locally and rarely metastasise; only in very few cases does invasiveness assume serious proportions. ${ }^{8}$ All patients reported upon with mucoepidermoid carcinoma underwent exenteration, and the early invasion of near-by voluntary muscle would tend to confirm that this may be the required procedure. This option was not readily open to us, since from the standpoint of visual acuity we were dealing with an only eye. The advanced age of the patient also argued in favour of a conservative approach, which in the event allowed her five years of good vision. Prognosis, now that further surgery has been declined, is poor: vision will be lost through exposure keratitis and optic atrophy.

A diagnosis of squamous cell carcinoma was made in a general pathology laboratory which received the specimen from the present patient before it was referred to this centre, when the mucoid element was identified. We believe that more of these growths may on further investigation and examination be found to be of mucoepidermoid type, but could have been missed because of the rarity of reports of such neoplasms at this site.

We thank Mr R Lester and Miss M Hurley for technical help, Mr S Travers for photographic assistance, and Miss C Tyner for secretarial work.

\section{References}

1 Brownstein S. Mucoepidermoid carcinoma of the conjunctiva with intraocular invasion. Ophthalmology (Rochester) 1981; 88: 1226-30.

2 Ni C, Wagoner MD, Wang WJ, Albert DM, Fan CO, Robinson N. Mucoepidermoid carcinomas of the lacrimal sac. Arch Ophthalmol 1983; 101: 1572-4.

3 Searl SS, Kriegstein HJ, Albert DM, Grove AS. Invasive squamous cell carcinoma with intraocular mucoepidermoid features: conjunctival carcinoma with intraocular invasion and diphasic morphology. Arch Ophthalmol 1982; 100: 109-11. 
4 Font RL, Gamel JW. Epithelial tumours of the lacrimal gland: an analysis of 265 cases. In Jakobiec FA, ed. Ocular and adnexal tumours. Birmingham, Ala: Aesculapius, 1978: 787-805.

5 Bambirra EA, Miranda D, Rayes A. Mucoepidermoid tumour of the lacrimal sac. Arch Ophthalmol 1981; 99: 2149-50.

6 Rao NA, Font RL. Mucoepidermoid carcinoma of the conjunctiva: a clinicopathologic study of five cases. Cancer 1976; 38: 1699-709.
7 Harry J, Ashton N. The pathology of tumours of the lacrimal sac. Trans Ophthalmol Soc UK 1968; 18: 19-35.

8 Thackray AC, Sobin LH. International Histological Classification of Tumours, No. 7. Histological typing of salivary gland tumours. Geneva: WHO, 1972.

Accepted for publication 30 December 1985. 